\title{
Teofania e niilismo: leituras \\ zizekianas de um haicai \\ de Adélia Prado
}

\section{Theophany and nihilism: zizekian's \\ readings of an Adélia Prado's haiku}

\section{Danilo Mendes}

Texto enviado em

29.03.2019

aprovado em

01.07.2019

V. 10 - N. $21-2020$

* Doutorando em Ciência da Religião pela

Universidade Federal

de Juiz de Fora com bolsa CAPES. Mestre em

Ciência da Religião pela mesma universidade.

Contato: danilo. smendes@hotmail.com 
expressa o Deus que vem do nada, mas o nada que vem de Deus.

Palavras-chave: Niilismo. Adélia Prado. Slavoj Žižek. Haicai. Mística.

\section{Abstract}

This text aims to contribute to the philosophy of religion from an interpretation of the Adélia Prado's poem "Artefato nipônico" (Japanese artifact) through the haiku's structure presented by Slavoj Žižek, having as key the concept of event, relying on the contributions from Martin Heidegger. In this way, the concepts of event, nothingness and God, will be related, presenting how literature can be, besides privileged locus of aesthetic experience, the starting point to understand the religious phenomenon. In this sense, we can point to a theory of religion between nihilism and theophany. The relationship between God and nothingness in Adelia's poem should not be understood as contradictory nor sequential. It means that there is, in our reading, a close relationship between the two terms, so that the first, as the disruption of the static landscape, is the movement that generates the event itself - and this is nothing. Starting from the three verses of this poem, we look for a way to conceptualize religion: extracting the philosophical consequences of this haiku. Finally, we indicate how nothingness can be understood as a mystical silence. Thus, we can point to a reverse theology: it does not express the God who comes from nothing, but the nothingness that comes from God.

Keywords: Nihilism. Adélia Prado. Slavoj Žižek. Haicai. Mystic.

\section{Introdução}

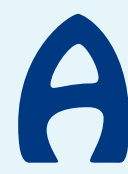

s abordagens de pesquisa entre religião e literatura são, pelo menos, três: a) pode-se verificar como uma literatura é constitutiva numa religião; b) pode-se analisar como a religião é constitutiva numa literatura; c) pode-se buscar a contribuição mútua entre religião e literatura, na medida em que a constituição dos campos se dá, em certa medida, de forma dialética. $O$ presente trabalho não assume nenhuma dessas formas pois, em vez delas, procura a contribuição que a literatura pode dar ao estudo da religião. Tal contribuição consiste na inversão de papéis entre literatura e filosofia da religião: não se busca somente como essa pode analisar de maneira apurada aquela, mas como a in- 
terpretação de poesia tem implicações relevantes para os estudos da religião. Aqui, como ainda ficará claro, a poesia de Adélia Prado implica pensar a religião como desfundamento e encontro com o nada. Essa perspectiva não torna nosso texto mais importante que outras pesquisas já realizadas, mas também não o diminui. Topograficamente, ela se encontraria ao lado de tais pesquisas por envolver os mesmo elementos e compartilhar o mesmo âmbito, mas de forma um pouco diferenciada. Se se pode pressupor esses lugares em que vagam as pesquisas, não é errôneo afirmar que esta passeia por um lado mais experimental em relação às outras.

Aqui, mais especificamente, procura-se perceber quais as possíveis contribuições que o poema "Artefato nipônico" de Adélia Prado (2007, p. 27) dá ao estudo da religião. Pode-se objetar que um pequeno poema japonês com a estrutura abrasileirada, um haicai, tem pouco a dizer e, portanto, pouco a contribuir. A esse equívoco a tradição cristã afirma a esterilidade da letra frente à criatividade vivificadora do espírito. Fazer jus ao espírito crítico do haicai de Adélia requer uma análise de mais do que as nove palavras que o compõe: necessita sensibilidade para perceber como elas compõe os versos e como os versos se relacionam entre si formando um todo. O espírito mora nos detalhes. Por isso a estrutura do poema determina a estrutura desse trabalho: cada verso é desenvolvido ponderando as significações que emanam de si diante do que uma estruturação tradicional propõe.

Para a possibilidade de realizar isto, deve-se afirmar um pressuposto que, apesar de óbvio, poderia ser questionado. O poema de Adélia é um haicai. Isto significa que pode e deve ser interpretado como tal. No joguete religioso, mais uma vez, deve-se perceber como ele dá em espírito e não em letra. Essa afirmação se refere à caracterização clássica de um haicai diante de dois tipos de estrutura que os unem: estrutura semântica e estrutura silábica. Embora o poema não respeite esta estrutura totalmente, isto é, não é construído com versos de 5, 7 e 5 sílabas poéticas respectivamente, apesar de possuir os tradicionais três versos, 
ele é construído semanticamente como um haicai, relacionando estaticidade, irrupção, e movimento, respectivamente. Além disto, Adélia o intitula fazendo referência à tradição japonesa e, num tom de brincadeira, denomina seu poema nipônico de artefato.

Se, como diz ela, seu poema é um artefato, aqui ele encontra um de seus usos. Mais do que experiência estética, esse artefato contribui para o estudo do fenômeno religioso relacionando grandes temas da filosofia contemporânea como Deus e nada. A proposta, aqui, é analisar estas contribuições através da proposta de Slavoj Žižek de estruturação do haicai tendo como chave o conceito de acontecimento. Desse modo, cada verso é analisado de acordo com a proposta zizekiana, numa dialética entre estrutura e semântica e, por fim, há uma abordagem de como o poema, no sentido atribuído pela estrutura, contribui para uma relação entre Deus e nada. Antes desta jornada, deve-se entender melhor o que seja este poema japonês e como Žižek entende sua estrutura.

\section{Haicai: história e estrutura}

Massaud Moisés, em seu dicionário de termos literários, define o haicai como "poema japonês caracterizado pela brevidade, compõe-se de três versos [...]" (1992, p. 269). Sobretudo por sua brevidade, esse poema, para Moisés, tende ao cômico e suas origens remetem ao século VIII. Todavia, só ganha definição estrutural como se conhece hoje no século XVII com Matsuo Basho¹ (1992, p. 170). Buscando uma espécie de retrato do novo em meio ao cotidiano repetitivo ${ }^{2}$, o haicai, em seus versos, "deve concentrar em reduzido espaço um pensamento poético el ou filosófico" (MOISÉS, 1992, p. 270). Para esse autor, por fim, uma das

1. O poeta brasileiro Paulo Leminski, também escritor de haicais, é autor de uma interessante biografia poética sobre este autor: Bashô (2013).

2. Para Massaud Moisés, o haicai "busca alcançar o Reino da Sensação, das melodias jamais ouvidas, das peregrinas emoções desencadeadas pela comunhão, instantânea e fugaz, com a eternidade e a imortalidade; expressar uma sensação nova, um imprevisto significado de súbito apreendido no espetáculo perene da vida e da Natureza, pela associação espontânea e alógica, de aspectos até então distantes ou separados" (MOISÉS, 1992, p. 270) 
características mais elementares e próprias do haicai é a novidade inesperada no ciclo da vida. Nele, "seres e mundos normalmente afastados de repente se aproximam" (1992, p. 270).

Tanto Moisés quando Paulo Franchetti em sua primorosa introdução à história do haikai (2012b, p. 9-54) apontam para a estrutura silábica de dezessete sílabas poéticas (5-7-5) como primordial no haicai tradicional. Todavia, na literatura brasileira, essa estrutura silábica nem sempre é respeitada: aqui, prefere-se o espírito deste pedaço de cultura nipônica em forma a esta divisão de sílabas ${ }^{3}$. Franchetti aponta que, todavia a partir do século XV, desenvolve-se uma estreita ligação entre a estética literária, a ética e a religiosidade 4 , "de tal forma que a reflexão sobre a literatura e a prática literária frequentemente deságuem em reflexão e prática religiosa" (2012b, p. 21). Essa ligação entre religião e literatura no Japão dos haicais não será fundamental para o desenvolvimento da técnica no Brasil, embora tenha influenciado o entendimento de Paulo Leminski (a partir do Zen) e de Adélia (com seu catolicismo de libertação).

O que se chama de espírito do haicai é uma série de elementos que compõem a atmosfera desta técnica. São eles, de modo geral, ligados à natureza e ao seu movimento. Capta-se, com o haicai, a duplicidade ambígua deste movimento: sua lentidão no que se refere à mudança das estações e, no limite, às mudanças topográficas; e a rapidez dos pequenos instantes que compõe sua dinamicidade estática: o pulo de um sapo, um pingo de chuva, uma nuvem que passa, o vento que balança a grama. Por isto, a natureza é a forma que predomina essa arte japonesa, sobretudo nas estações do ano - por meio das quais serão classificados os haicais nas antologias clássicas. Esse lugar central que a natureza possui no tema dos haicais é, em certa medida, o espírito que os constitui como fotografias literárias que captam a dualidade fugaz (ou

3. Sobre este tema, recomenda-se o texto O haikai no Brasil também de Franchetti (2012a).

4. "No Japão como na China, as questões éticas, religiosas e estéticas são frequentemente as mesmas" (FRANCHETTI, 2012b, p. 21). 
a fugacidade dual) da própria vida.

Outra possibilidade de apontamento de um espírito do haicai é observar sua estrutura de sentido. Isso não significa somente definir sua separação silábica como fundamental, mas, sobretudo, como cada um de seus versos cumpre um papel dentro da imagem formada pelo haicai e, consequentemente, como se relacionam entre si. Indicar a relação entre forma poética e significado semântico ${ }^{5}$ no haicai é imprescindível nesse momento. O modo curto, de apenas três versos, pelo qual o haicai se estabelece não demonstra mera velocidade de leitura, mas indica a própria fugacidade frágil de seu conteúdo. O haicai não poderia, nesse sentido, ser uma longa descrição poética pormenorizada de um acontecimento - haveria uma relação desproporcional entre sua forma e o conteúdo. Por isso os poucos versos de poucas sílabas são a forma irredutível e inalterável que sintonizam com o âmago semântico de seu próprio conteúdo. A fragilidade estrutural é a fugacidade do conteúdo. O significado corresponde à forma por meio da representação de um fato momentâneo. A forma corresponde ao significado na pequena estrutura de três versos.

No objetivo estabelecer como se dá essa relação, Slavoj Žižek apresenta uma proposta de interpretação para a estrutura do haicai tendo como chave de leitura o conceito de acontecimento (tema da obra em que apresenta tal proposta). Para ele, a noção de acontecimento é central na filosofia budista em dois níveis: de um lado no acontecimento da iluminação e, de outro lado, na percepção de acontecimentos fugidios como no haicai. Para Žižek,

A regra dos três versos de um poema haikai é bem justificada: o primeiro apresenta a situação anterior ao

5. A relação entre forma e conteúdo, em geral, torna-se interessante na medida em que se estabelece enquanto dialética. Nesse sentido, não haveria certa hierarquia ou sobreposição do conteúdo sobre a forma ou o contrário, mas uma interdependência fundamental. Sobre como se dá essa relação na verdade religiosa de Kierkegaard, recomendamos o trabalho de Paulo Henrique "O labirinto existencial-religioso: a dialética entre forma e conteúdo no estilo da obra kierkegaardiana” (2018). 
acontecimento (um velho lago de águas tranquilas, um vaso sanitário de águas calmas); o segundo assinala um corte nessa inatividade, a intervenção que perturba a paz e vai gerar o acontecimento (um sapo pula, sento-me num vaso sanitário); e o último verso dá nome ao próprio e fugidio acontecimento (o som do impacto) (ŽIŽEK, 2017, p. 146) ${ }^{6}$.

A esta proposta seguirá a releitura do poema de Adélia Prado, uma das brasileiras que se aventuraram a esta técnica. Diz Massad Moisés "Em que pese à sua dificuldade arquitetônica de responder à tendência oriental para a condensação sentenciosa, na Literatura Brasileira o haicai tem sido cultivado por uma série de poetas" (MOISÉS, 1992, p. 271). Desses, escolhemos o poema Artefato nipônico:

A borboleta pousada

Ou é Deus

Ou é nada (PRADO, 2007, p. 27).

\section{A borboleta pousada}

A imagem que Adélia pinta com suas palavras, seguindo a proposta zizekiana, é uma situação comum, anterior ao principal do poema, o acontecimento. Todavia, pode-se afirmar que esta imagem, dentro da estrutura do haicai, revela mais que isso. A borboleta pousada é a estaticidade da natureza frente à observadora. Isto é, ela representa o que está dado antes de qualquer acontecimento ou quebra do fluxo. Em outras palavras, a borboleta é a faticidade diante da qual Adélia se vê impelida a interpretar. É, em grande medida, a borboleta o chão em que a autora pisa, a fotografia literária de onde nasce o acontecimento que dá à sua poesia valor de haicai. Nesse sentido, a percepção da borboleta como paisagem estática é sua visão prévia.

6. Os exemplos entre parêntesis referem-se a dois haicais apresentados anteriormente pelo autor para ilustrar sua argumentação de que não há idealização estética neste tipo de poema, mas o que realmente importa é o acontecimento-impacto, não importa quão inadequado ele seja. Os exemplos são, respectivamente, um haicai de Bashô e uma releitura japonesa popular: "Velho lago/ Um sapo mergulha/ Tchum [...]. Vaso sanitário com água suja/ Sento-me nele/ Tchum" (ŽlŽEK, 2017, p. 145). 
No pensamento de Martin Heidegger, o conceito de hermenêutica tem um papel fundamental: o humano realiza não só a interpretação de textos, mas da própria vida a todo momento. Mas o que este humano interpreta? A faticidade. O conceito de fático não é simplesmente o que é natural, mas "deve ser compreendido apenas através e pelo conceito do 'histórico'” (HEIDEGGER, 2014, p. 14)7. Em outras palavras, diz ele: "O conceito de faticidade: nosso ser-aí [Dasein] próprio em cada caso" (HEIDEGGER, 2013, p. 37). Isso significa que a faticidade que ao humano cabe interpretar não é uma estrutura fixa da qual as interpretações surgem, mas um mundo sempre em mutação, dado sempre diferentemente em cada caso. Por isso o autor evoca a ideia de conceito do histórico: a fim de salientar a dinâmica da faticidade. Entender a borboleta pousada como faticidade é entender que ela se deu desta forma a Adélia, num momento único em que foi, por ela, percebida. É a partir desta faticidade que o interpretar adeliano, do qual parte o haicai como seu primeiro verso, terá seu início.

Todavia, essa interpretação contínua não se dá sem pressupostos, isto é, sem visões prévias. Diz Heidegger que "A interpretação de algo como algo funda-se, essencialmente, numa posição prévia, visão prévia e concepção prévia. A interpretação nunca é apreensão de um dado preliminar, isenta de pressuposições" (2015, p. 211). Apontar isto na poesia de Adélia não é somente apontar para a situação que ela interpreta, mas mostrar o que já está pressuposto no próprio ato interpretativo. A borboleta pousada não é sua visão prévia, mas a condição da borboleta pousada como primeiro verso do haicai o é. O que isso significa? Que Adélia pressupõe, antes ainda da interpretação, que o pouso da borboleta é o fim de um ciclo de movimentos, isso é, o breve momento em que se aquieta a natureza e sua dinâmica permanece estática. Nesse sentido, o pouso é repouso, descanso da borboleta enquanto aquela que voa.

7. Para ele, "o caráter peculiar da experiência fática da vida é o 'como eu me coloco diante das coisas', o jeito e a maneira de experimentar" (HEIDEGGER, 2014, p. 16). Neste sentido, Adélia é heideggeriana em seu haicai, pois, "o ponto de partida do caminho para a filosofia é a experiência fática da vida" (HEIDEGGER, 2014, p. 15). 
O pouso, entretanto, só é repouso quando percebido como movimento dialético do vôo: só se voa porque se pousa, só se pousa porque se voa. Esta mútua dependência entre os dois atos da borboleta demonstra que eles não são opostos entre si, mas complementares. De certo modo, a semelhança de Heidegger, pode-se afirmar que a essência do pouso é o próprio vôo, na medida em que ele é percebido como consumação do ato de voar ${ }^{8}$. O pouso só é a condução à plenitude da essência de voar enquanto está sempre em referência a ele. Nos termos fundamentais do haicai, diz-se que a fugacidade do pouso, enquanto complemento do vôo, é primordial: o pouso mantém, apesar do caráter estático, a provisoriedade que um haicai enquanto tal requer. Estaticidade fugaz: movimento provisório, pouso que quando é já decolou em vôo. A faticidade estática do pouso é, potencialmente, o próprio acontecimento. Por não conter em si o inesperado, o que quebra o pouso, em Adélia, não é o vôo, mas Deus.

\section{Ou é Deus}

Se, nesta leitura a partir de Slavoj Žižek, a borboleta pousada é a prévia ao acontecimento, o corte na inatividade, "a intervenção que perturba a paz" (ŽlŽEK, 2017, p. 146) é Deus. Melhor seria, aqui, inverter a sequência e afirmar: Deus é a intervenção contra a paz. Como um dos vocábulos que em si mesmo nada dizem, a concepção de Deus é, neste ponto, fundamental para uma boa releitura do haicai. Isso se dá porque, usualmente, pensa-se Deus como o ente que estrutura e fundamenta o mundo. Nesse sentido, não há corte com esta noção quando ela afirma a intervenção divina acontece. Diferenciam-se, todavia, ao apontar o direcionamento desta intervenção: enquanto na noção usual, aqui desenhada, Deus é a ordem que estrutura o mundo e mantém cada coisa em seu devido lugar, na releitura do haicai, Deus é o corte com a ordem,

8. Aqui faz-se referência ao início de Sobre o humanismo onde diz Heidegger que "A essência do agir, no entato, está em con-sumar. Con-sumar quer dizer: conduzir uma coisa ao sumo, à plenitude de sua Essência" (1995, p. 23-24). 
intervindo contra a paz.

A primeira noção aponta para o Deus fundamento que é, em grande medida, o Deus da metafísica. É justamente este Deus que Nietzsche anuncia a morte: o "Deus moral-metafísico" (VATTIMO, 2004, p. 29). A ele está ligada a ideia de mundo como cosmos, como criação ordenada, organizada e regida por uma pessoa. Nesse sentido é que a intervenção se dá, para manter a ordem criada por ele mesmo e, enfim, para a manutenção de seus desígnios eternos. Esse interventor que está sempre presente como ordem ou providência ${ }^{9}$.

O Deus desta releitura do haicai, pelo contrário, não é aquele que intervém pela ordem, mas contra ela. Não é ele a força que estrutura o mundo como dado, mas exatamente o que vai contra esta estrutura. Assim, não é mais uma presença transcendente afirmativa, no sentido de que não se impõe sobre o mundo, mas se retira constantemente de suas construções a fim de torná-las obsoletas. É este Deus que aponta Frederico Pieper como a força motriz da religião nos filmes que analisa em Religião e cinema. Afirma ele que a religião é ambígua, pois "Se de um lado fundamenta mundos, cria sentido, faz a passagem do caos ao cosmos, ela não se reduz a isso. [...] Ela não apenas estabelece sentido, mas conduz também à desfundamentação. Não apenas constrói mundos, mas também os subverte" (PIEPER, 2015, p. 227-228).

Assim, o segundo verso do haicai não pode ser lido sequencialmente em relação ao primeiro, isto é, como continuação dele. Se lido, inverter-se-ia absolutamente a novidade que o Deus do segundo verso instaura. Ele já não seria o corte com a ordem captada pelo pouso da borboleta, mas seria a fundamentação cósmica que permitiria tal pouso. Essa leitura, que seria a mais adequada caso não fosse um haicai interpretado através de Žižek, faz par com a primeira noção de Deus aqui descrita,

9. Na própria teologia a doutrina da providência de um Deus intervencionista é criticada. Mardones, por exemplo, afirma que "A apelação à providência apresenta uma face perigosa de injusta arbitrariedade, por um lado, ou de legitimação de uma situação social, por outro, quando se atribui a Deus a boa ou a má situação social” (MARDONES, 2009, p. 49). 
como ordenador. Seria ele, a partir da sequencialidade dos versos, condição de possibilidade da consumação do vôo, o pouso.

O papel, então, do segundo verso diante do haicai e de sua interpretação zizekiana é fundamental: ele rompe com a estática fugaz do primeiro verso, desinstaura a ordem - que seria estabelecida por outro Deus, mas não por este, e abre caminho para o acontecimento que é a essência do poema. Somente a partir desta desfundamentação que o Deus do segundo verso promove, a novidade do acontecimento pode se dar. Desta forma, não só abre a possibilidade, mas o Deus é aquele que instaura o acontecimento, mesmo que negativamente, isto é, pela desfundamentação. É desse Deus que vem o acontecimento, é deste Deus que vem o nada.

\section{Ou é nada}

Primeiramente, seguindo o plano de Žižek, faz-se necessário salientar que, apesar do uso de "ou/ou" pela autora, o segundo e o terceiro versos não podem ser entendidos como opostos. Isso significa que a relação entre Deus e nada não é de contradição, mas de sequência. Na proposta zizekiana, esse terceiro verso é o que dá nome ao próprio acontecimento em si, ou seja, evoca à linguagem poética o próprio acontecer. Tal acontecer não é externo à realidade dos dois versos anteriores, mas provém, justamente, da estaticidade do primeiro verso e no movimento instaurado no segundo. Assim, nem oposição nem complementação poderiam explicar a relação deste terceiro verso com os outros dois. Estabelece-se, aqui, a consequência. A partir da faticidade e do movimento, o acontecimento tem seu lugar e sua essência: ele acontece.

Para a rememoração do que seja, para Žižek, este acontecimento, deve-se retornar ao clássico haicai de Bashô que serve como exemplo: "Velho lago/ Um sapo mergulha/ Tchum" (ŽlŽEK, 2017, p. 145). O acontecimento, nesta perspectiva é somente o barulho da água. Nada além de sua evocação está contida no poema, somente a onomatopéia que o 
nomeia: tchum. Trazer esse detalhe à leitura do haicai de Adélia se faz importante porque elimina a possibilidade de confusão sobre o que seja o nada do terceiro verso. Por mais que a letra minúscula não o nomeie como substantivo próprio, poder-se-ia objetar que o nada, se em oposição a Deus, seria um nada maiúsculo, isto é, uma afirmação do nada - que, em termos metafísicos, não seria menos que a nova configuração de um Deus fundamento, apenas com outro nome. Todavia, isto não se dá porque apenas nomeia o barulho do acontecimento, isto é, chama pelo nome precário que é possível, visto que é um acontecimento tão fugidio quanto um barulho sobre um lago: ondas criadas que em um instante já se esvaíram.

Nessa releitura que aqui é proposta, configura-se o acontecimento do nada, isto é, o nada acontece. Por mais que, então, pareça lógico, o acontecimento do nada não é a volta do estático primeiro verso, numa espécie de eterno retorno do mesmo. Muito menos a anulação de tudo. O nada, aqui, não é simplesmente uma ausência de fundamentos, mas justamente a presença de uma ausência de fundamentos. Neste sentido, tomar o nada como acontecimento é uma perspectiva totalmente diferente da teologia negativa, por exemplo. Enquanto esta argumenta a impossibilidade de tratar positivamente de Deus, por isso toma uma postura apofática na qual cala-se diante de uma presença profunda. $\mathrm{O}$ nada como acontecimento não afirma uma presença da presença, nem mesmo do nada, mas somente depara-se com a desfundamentação - e pode falar sobre ela em algum âmbito.

Pode-se referenciar, novamente, o anúncio nietzschiano da morte do deus moral-metafísico, todavia, já em suas consequências. Diz o aforismo 108 de A gaia ciência: "Deus está morto; mas tal como são os homens, durante séculos ainda haverá cavernas em que sua sombra será mostrada" (NIETZSCHE, 2012, p. 126) ${ }^{10}$. As figuras utilizadas por Friedrich Nietzsche são, aqui, tão sumariamente importantes: a caverna de Deus não nos obscurecerão mais a vista?" (NIETZSCHE, 2012, p. 127). 
remete à alegoria de Platão, símbolo da tradição metafísica que considerava o ser como fundamento da realidade que poderia ser objetivamente apreendida; a sombra deve ser interpretada como o resquício da metafísica na qual habita a filosofia, mesmo após o anúncio da morte deste fundamento ${ }^{11}$. A sombra de Deus é o nada.

Assim, o acontecimento do nada deve, antes de qualquer conclusão, ser levado em conta como nada que vem de Deus. O Deus do segundo verso, desfundamentalizador, visto que é ativo na obra de desfundamentalização que abre espaço para o nada, é o que possibilita o acontecimento. Realiza-se, assim, uma espécie de teofania inversa: enquanto a teofania pode ser conceituada como a presença repentina de Deus, isto é, o Deus que preenche o espaço do nada, o haicai de Adélia aponta para um nada que vem de Deus. Todavia, esta inversão não pode ser considerada simétrica, sobretudo na medida que se reconhece que o nada não ocupa o lugar de Deus, mas deixa-o vazio.

\section{Da teofania ao niilismo: o nada que vem de Deus}

A releitura do haicai de Adélia Prado pode, então, contribuir com uma conceituação da religião que articula as noções de niilismo e teofania de um modo muito característico. Nesta teofania inversa de Adélia, encontram-se a estética da estática borboleta, a ética desarticuladora do Deus e o acontecimento do nada. Essa parcial conclusão é encontrada somente na releitura do haicai através da proposta de Žižek. Resta, então, um aprofundamento de como se dá a relação entre o Deus que rompe com a ordem e sua sombra que toma. Em termos literários, busca-se entender como se relacionam o segundo e o terceiro verso do haicai. Em termos nietzschianos, busca-se entender como niilismo e cristianismo rimam $^{12}$.

11. Possivelmente a figura da sombra também seja uma alusão arisca ao ideal iluminista de conhecimento absoluto.

12. Referência ao aforismo 58 de $O$ anticristo: "Niilista e cristão: duas coisas que rimam, e não apenas rimam..." (NIETZSCHE, 2016, p. 74). 
Convém, nesse momento, evocar o pensamento de Alain Badiou que caracteriza acontecimento como "esse gesto de arrancar a máscara, porque não se trata de algo interior à própria representação. É algo que vem de alhures, de um alhures interior, se assim podemos dizer, ainda que esse alhures seja dificilmente situável e, infelizmente, muitas vezes improvável" (BADIOU, 2017, p. 28). Considera-se importante este pensamento uma vez que está alinhado com a proposta zizekiana de caracterizar não só o acontecimento, mas de onde parte o movimento que o gera. Assim, a consequência dessa noção para a leitura do haicai já pode ser analisada: sendo Deus o corte no estático que acaba no acontecimento, ele não é somente possibilidade do acontecimento, mas causa. E mais: o acontecimento não só é criado por esse Deus, mas é gerado por ele, no sentido de que vem do interior do próprio Deus. Todavia, o nada não é o que está por trás da representação de Deus, que pode ser interpretado como o Deus da ordem, mas é o "real" no vocabulário de Badiou, por trás desta máscara. Por fim, não seria errado afirmar que o acontecimento é o próprio desmascaramento.

Nesse sentido, teofania e niilismo estão mais do que perto. Se o acontecimento-nada se dá no próprio desmascaramento de Deus, no haicai de Adélia, teofania é niilismo. Esta afirmação carrega em si um perigo: de transformar-se numa absolutização do nada e numa afirmação ateísta - que se constitui tão metafísica quanto a crença mesma ${ }^{13}$. Por isso, este niilismo deve ser entendido na esteira do pensamento de Gianni Vattimo, para quem um posicionamento de hermenêutica niilista é a chance de manter a racionalidade no ocidente após a dissolução da metafísica. Afirma ele que

13. Heidegger expressa a absolutização do nada de forma irônica em Sobre o humanismo: "Tudo que não se enquadrar na bitola do positivo que se quer e se conhece, é lançado na vala já adrede preparada da simples negação que, negando tudo, termina no Nada e assim completa o 'niilismo'. Por esse caminho lógico, tudo sucumbe ao niilismo, mas num niilismo que se inventou com a ajuda da própria lógica. Será mesmo que a 'oposição' (das Gegen) que um pensamento promove diante das opiniões habituais, conduz à simples negação e ao negativo?” (1995, p. 76). 
O sentido do niilismo, porém, se não deve, por sua vez, resolver-se numa metafísica do nada - como aconteceria se imaginássemos um processo em que, no final, o ser não é, e o não-ser, o nada, é - mas só pode ser pensado como um processo indefinido de redução, de adelgaçamento, de enfraquecimento (VATTIMO, 2000, p. 106).

Teofania é niilismo nesse sentido: não como uma nova metafísica que substitui Deus pelo nada, mas como afirmação de que de Deus vem o nada que possibilita um novo começo. Teofania é niilismo não enquanto beco sem saída, mas como saída do beco em que a teofania da objetividade colocou o humano moderno ${ }^{14}$. Isto se dá porque é nesta ausência de Deus que surgem as possibilidades de afirmação do humano. É no acontecimento desmascarador que se encontra a teofania niilista - o nada que vem de Deus é a condição de possibilidade para que tudo venha a acontecer. Funda-se, então, uma nova possibilidade de leitura, que liga o terceiro verso ao primeiro, não de modo retroativo, mas de subversão da sequência do haicai. O terceiro verso, que poderia ser lido como o resultado dos dois anteriores, na verdade é a condição primeira para que o primeiro e o segundo verso sejam. É somente diante do nada que se pode fundamentar o ser da borboleta pousada e de Deus. Neste sentido, o próprio Deus não é fundamento, mas é fundamentado pelo desfundamentalizante nada.

Nessa perspectiva, por fim, encontra-se Rubem Alves, para quem o "discurso religioso fala do ausente" (ALVES, 1999, p. 166) ${ }^{15}$. Deus, para ele, é sempre a presença de uma ausência, diante da qual nada pode ser afirmado absolutamente. Assim, o Deus de Rubem Alves parece ser o Deus de Adélia: o Deus de quem o nada acontece. Unem-se as compreensões: falar de presença da ausência é reconhecer que há, quando se fala de Deus, um nada irreparável donde surgem as novas reais

14. O que se chama de teofania da objetividade foi definido por Volpi como niilismo: "O niilismo é, pois, a 'falta de sentido' que desponta quando desaparece o poder vinculante das respostas tradicionais ao porquê da vida e do ser" (VOLPI, 1999, p. 55).

15. Para Alves, o anúncio da morte de Deus em Nietzsche é possibilidade para novos caminhos de crença: "Deus está presente quando está ausente" (ALVES, 1972, p. 34). 
possibilidades. O poema de Adélia, então, fala de uma religiosidade, isto é, uma maneira de habitar o mundo, que se dá diante de um Deus desmascarado em nada. Isso, nesta leitura, não é sinônimo de ateísmo, mas sinônimo de esperança: somente no nada, tudo pode vir a ser.

Contribui com essa leitura a ideia de Paul Tillich que, ao falar sobre o aspecto religioso na cultura secular, sendo esta a forma da religião enquanto que a religião seria sua substância ${ }^{16}$ atribui a Deus uma abertura, um ainda não que é presente na sociedade. Mais do que um fenômeno que encontra niilismo na teofania desavisadamente, esse autor vê uma espécie de correspondência entre os termos como um destino da cultura, que não é necessariamente ruim a fé - o que seria se entendido como um secularismo. Diz Tillich que o ideal de uma educação teônoma, isto é, que não se confunde com heterônoma nem autônoma, encontra-se um pouco distante de ser alcançado, "Mas é possível chegar a esse ideal quando aceitarmos o vazio que é o destino de nossa época, recebendo- como o 'vazio sagrado' capaz de qualificar e transformar o pensamento e a ação" (TILLICH, 1992, p. 93).

\section{O nada como silêncio místico}

Esse vazio, justamente por ser nada, é múltiplo de possibilidades. É dele, por exemplo, que nasce um fenômeno inerente à condição humana: a angústia ${ }^{17}$. Na poesia essa teofania nilista pode se dar como silêncio. Como na relação entre pouso e vôo, o silêncio não é somente aquele que cessa a palavra, mas aquele que lhe dá seus sentidos mais profundos e, em certo sentido, mais próprios. Na medida em que a palavra só o é porque em algum momento se cala, o silêncio está dentro da própria essência do que a palavra é.

Antonio Cicero, buscando o conceito do que seja poesia, contribui

16. Sobre isso, ver TILLICH, 19992, p. 85.

17. A respeito da angústia deve-se ler O conceito de angústia (2014) de Kierkegaard, para quem o nada é objeto deste fenômeno. 
para o pensamento dessa relação. Ele discorda radicalmente dos dicionários em seus verbetes que fornecem definições do termo como arte de fazer versos. Diz Antonio Cicero: "Pois bem, nesse caso quase todo mundo [dicionários] está errado, [....] nem todas as sequências de versos chegam a constituir verdadeiros poemas" (CICERO, 2017, p. 44). Isso não significa que os poemas não sejam, também, constituídos de versos, mas que a eles é intrínseca uma característica muito mais marcante: a presença do silêncio. Por isso o autor fala da "poesia entre o silêncio e a linguagem do entendimento" (CICERO, 2017, p. 46).

Enquanto se instaura entre os dois pontos, a poesia é o resultado por ambos. Ela, que se manifesta por meio da linguagem do entendimento e do silêncio, simultaneamente procura essa linguagem e a falta dela. Fala sobre tudo até os limites da razão. Cala-se sobre o que não pode entender ${ }^{18}$. Diz Cicero que "O silêncio é o ser do poeta e de seus ouvintes reais e virtuais. A poesia é o resultado da escuta desse silêncio" (2017, p. 59). Isso indica que o nada está presente não só na constituição da teofania, mas da própria poesia como silêncio.

Entre teofania e poesia, ambos marcados pela falta, pelo nada, pelo silêncio, há mais do que mera coincidência. O nada que vem de Deus é o próprio silêncio que constitui a palavra poética. Nesse sentido, a sua busca pela linguagem do entendimento é uma busca mística. A fala do poema é a própria busca pelo Deus de quem o nada vem. Aqui Cicero é mais uma vez preciso na construção da relação: "A voz da poesia encontra-se embaixo do falar porque a apreensão estética é mais profunda do que a apreensão instrumental do ser, que é a do 'falar'. Quando este se dá, ela se cala, pois não é por ele alcançada" (2017, p. 60). O falar é a busca que está sempre aquém do que o poema deseja. $O$ falar cessa encontrando o silêncio da poesia. Esse silêncio é místico porque é o nada teofânico. Ele deseja o próprio Deus, mas encontra o nada e, por isso, silencia.

18. Aqui a referência a Wittgenstein e os limites da linguagem parece clara: "7. Sobre aquilo de que não se pode falar, deve-se calar" (2017, p. 261). 


\section{Considerações finais}

Não é novidade que a literatura secular tem sido notada como lugar primordial de expressão da experiência com o sagrado. Mais do que expressão de religiosidade, a os estudos de literatura na ciência da religião têm sido acolhidos como forma de questionamento e reflexão sobre a religião. Nosso texto, contudo, não teve por objetivos pensar somente essas relações, mas pensar como a literatura pode questionar até mesmo o próprio sentido em que caminham as pesquisas sobre religião. Assim, a hermenêutica, um tanto experimental, que foi realizada no "artefato nipônico" de Adélia Prado não considerou somente o alcance religioso de suas consequências, mas desaguou numa densa questão sobre qual seja o próprio objeto da religião.

Nessa referência o texto foi construído: avaliar as relações e contrações entre os conceitos de nada e deus não são somente objeto da teologia (o que não deve, de modo algum, ser entendido como inferior), mas correspondem à questão fundamental da ciência da religião: a teoria da religião. Se toda religião é em relação a seu objeto de devoção, que independe de uma investigação sobre sua realidade, não é arriscado afirmar que a figura de tal devoção determina o sentimento religioso do indivíduo, ou grupo, e, no limite, determina o modo como o religioso habita e constrói seu mundo. Investigar o fundamento sobre o qual repousa esta figura da devoção é, então, essencial para a construção de qualquer pesquisa neste campo.

Assim, respondendo ao apelo da linguagem da releitura aqui realizada, pode-se dizer que o acontecimento do desmascarar é essa investigação sobre o fundamento e a essência do deus da religião. Entre o Deus ordenador e o nada desfundamentalizador, encontra-se a devoção da religião e sua prática. Adélia Prado, com seu haicai, lança luz sobre esta investigação, sobre os estudos filosóficos da religião e comprova que a literatura não é só lugar privilegiado de experiência estética, mas abismo necessário sobre o qual repousam fortes críticas filosóficas ao 
fazer acadêmico, neste caso, da religião. A contribuição desta Adélia à la Žižek aos estudos de religião é o questionamento sobre a presença de uma ausência que, em si, possibilita as diversas cotidianidades em suas fugacidades e belezas. Partimos da expectativa de que a própria literatura postulasse as bases para o estudo da religião, ou antes, que dela brotasse o objeto de estudo - por isso indicamos tal contribuição. Reiteramos, portanto: o nada que vem de Deus, esse silêncio místico, é o desfundamento que proporciona ao humano uma expectativa futura presente que sem ser ilumina o que ainda é.

\section{Referências}

ALVES, Rubem. Deus Morreu - Viva Deus! In: ALVES, Rubem; MOLTMANN, Jürgen. Liberdade e Fé. Rio de Janeiro: Tempo e Presença, 1972. p. 9-34.

ALVES, Rubem. O suspiro dos oprimidos. São Paulo: Paulus, 1999.

BADIOU, Alain. Em busca do real perdido. Belo Horizonte: Autêntica editora, 2017.

CICERO, Antonio. A poesia e a crítica: ensaios. São Paulo: Companhia das Letras, 2017.

FRANCHETTI, Paulo. O haikai no Brasil. In: FRANCHETTI, TAEKO (org.) Haikai: antologia e história. Campinas: Editora da Unicamp, 2012a. p. 195-211.

FRANCHETTI, Paulo. Introdução. In: FRANCHETTI, TAEKO (org.) Haikai: antologia e história. Campinas: Editora da Unicamp, 2012b. p. 9-54.

HEIDEGGER, Martin. Fenomenologia da vida religiosa. Petrópolis: Vozes; Bragança Paulista: Ed. Uni. São Francisco, 2014.

HEIDEGGER, Martin. Ontologia: (hermenêutica da faticidade). Petrópolis: Vozes, 2013.

HEIDEGGER, Martin. Ser e tempo. Petrópolis: Vozes; Bragança Paulista: Ed. Uni. São Francisco, 2015.

HEIDEGGER, Martin. Sobre o humanismo. Rio de Janeiro: Tempo brasileiro, 1995.

KIERKEGAARD, Soren, $O$ conceito de angústia: uma simples reflexão psicológico-demonstrativa direcionada ao problema dogmático do pecado hereditário. Petrópolis, RJ: Vozes, 2014. 
LEMINSKI, Paulo. Bashô. In: LEMINSKI, Vida: Cruz e Souza, Bashô, Jesus e Trótski - 4 Biografias. São Paulo: Companhia das Letras, 2013. p. 79-154.

LOPES, Paulo H. S. O labirinto existencial-religioso: a dialética entre forma e conteúdo no estilo da obra kierkegaardiana. Dissertação (Mestrado em Ciências da religião). Juiz de Fora: Universidade Federal de Juiz de Fora, 92p., 2018.

MARDONES, José Maria. Matar nossos deuses: Em que Deus acreditar? São Paulo: Editora Ave-Maria, 2009.

MOISÉS, Maussad. Dicionário de termos literários. São Paulo: Cultrix, 1992.

NIETZSCHE, Friedrich. $O$ anticristo: maldição ao cristianismo: Ditirambos de Dionísio. São Paulo: Companhia das letras, 2017.

NIETZSCHE, Friedrich. A gaia ciência. São Paulo: Companhia das letras, 2012.

PIEPER, Frederico. Religião e cinema. São Paulo: Fonte editorial, 2015.

PRADO, Adélia. A faca no peito. Rio de Janeiro: Record, 2007.

TILLICH, Paul. A era protestante. São Paulo: Ciências da religião, 1992.

VATTIMO, Gianni. Depois da cristandade. Rio de Janeiro: Record, 2004.

VATTIMO, Gianni. O vestígio do vestígio. In: DERRIDA, J.; VATTIMO, G. A religião: o seminário de Capri. São Paulo: Estação Liberdade, 2000. p. 91-107.

VOLPI, Franco. O niilismo. São Paulo: Loyola, 1999.

WITTGENSTEIN, Ludwig. Tractatus Logico-Philosophicus. São Paulo: Ed. Da Universidade de São Paulo, 2017.

ŽIŽEK, Slavoj. Acontecimento: uma viagem filosófica através de um conceito. Rio de Janeiro: Zahar, 2017. 